\title{
GENDER AND AGE ASPECTS OF BIOENERGETICS PROCESSES IN EXPERIMENTAL PASSIVE TOBACCO SMOKING AND MONOSODIUM GLUTAMATE ADMINISTRATION
}

\author{
A. V. Rutska, I. Ya. Krynytska \\ I. HORBACHEVSKY TERNOPIL STATE MEDICAL UNIVERSITY, TERNOPIL, UKRAINE
}

Background. Active smoking and exposure to passive smoke are responsible for more than 5 million deaths each year. At the same time, a characteristic feature of present food technologies is the use of food additives that are not always safe for human health, such as monosodium glutamate (MSG).

Objective. The aim of the research was to determine the changes in mitochondrial enzymes activity in rats in case of passive tobacco smoke combined with prolonged administration of MSG in the sex and age aspects.

Methods. The evaluation of bioenergetics processes in the mitochondria of circulating neutrophils was carried out using succinate dehydrogenase (SDG) and cytochrome oxidase (CO) activity.

Results. Passive tobacco smoke combined with the MSG administration in mature male-rats is accompanied by a significant inhibition of bioenergetics processes, as evidenced by a decrease in succinate dehydrogenase activity by $47.1 \%(p<0.001)$ compared to the intact animals, which is by $27.9 \%(p<0.001)$ below this index in case of the isolated effect of tobacco smoke and reduction of cytochrome oxidase activity by $27.5 \%(p<0.001)$ compared to the control group.

Conclusions. Thus, the findings suggest that low dose intake of monosodium glutamate enhances the ability of tobacco smoke to disrupt the cell's bioenergetics processes by affecting the respiratory chain function and generation of ATP. Therefore, it is advisable to investigate the established toxic doses of E621, as well as to study the molecular mechanisms of the 'safe' (allowed) doses of MSG effect on a living organism.

KEY WORDS: passive tobacco smoking; monosodium glutamate; cytochrome oxidase; succinate dehydrogenase.

\section{Introduction}

The WHO estimates that in 2015 there was about 1.1 billion adult smokers worldwide, representing nearly a quarter $(22 \%)$ of the global adult population. Number of women of reproductive age, who smoke, is also increasing. It is expected that by 2025 more than 500 million women will be smokers, accounting for about $20 \%$ of the global female population [1-2]. According to Solomenchuk T. M., in Ukraine the prevalence of smoking among women has tripled over the past 30 years [3].

Over 6 million people die from tobacco each year. More than 5 million of those deaths are the result of direct tobacco use while more than 600,000 are the result of nonsmokers being exposed to secondhand smoke. Secondhand smoke is a major health hazard, especially for infants and children. In the United

Corresponding author: Inna Krynytska, D.Med.Sci., Professor, Dept. of Functional and Laboratory Diagnostics, I. Horbachevsky Ternopil State Medical University, 1 Majdan Voli, Ternopil 46001, Ukraine.

Tel.: +380964790616

E-mail: krynytska@tdmu.edu.ua
States, it has been estimated that $43 \%$ of children aged from 2 months to 11 years live in a home with at least one person that smokes. The prevalence of passive infant smoking was reported to be around $40 \%$ in Europe as well [4].

At the same time, the characteristic feature of present food technologies is the use of food additives. One of the most common food additives in Ukraine as well as in Europe is monosodium glutamate (MSG). Encoded E621, it is a food additive from a group of flavor enhancers, used in a wide range of foods, such as soups, sauces, mixed condiments, chips, meat products, and puddings. Despite its taste stimulation and improved appetite enhancement, reports indicate that MSG is toxic to human and experimental animals [5].

An important role in the implementation of toxic action of xenobiotics is the violation of the energy supply in a cell. The most toxic metabolites, as well as products of their initiated lipoperoxidation disturb oxidation of substrates with dehydrogenases, transport electrons 
along the respiratory chain, causing the uncoupling of mitochondrial oxidative phosphorylation. Irreversible disorders in the structure and functioning of mitochondria, caused by the action of excessive amounts of reactive oxygen species (ROS), cause displacement of energy metabolism towards increasing the intensity of glycolysis and inhibition of oxidative phosphorylation [6].

The aim of this investigation was to determine the changes of mitochondrial enzymes activity in rats in case of secondhand tobacco smoke combined with prolonged administration of monosodium glutamate in the sex and age aspects.

\section{Methods}

Experimental studies were conducted on 32 inbred mature white male rats weighing 180$200 \mathrm{~g}, 32$ mature nonlinear white female rats weighing $180-200 \mathrm{~g}$ and 32 nonlinear immature white male rats weighing $60-80 \mathrm{~g}$.

Each group of animals was divided into four subgroups: the $1^{\text {st }}$ - the intact rats $(n=8)$; the $2^{\text {nd }}$ - the rats with modeled passive tobacco smoking $(n=8)$; the $3^{\text {rd }}$ - the rats, which were injected with monosodium glutamate $(n=8)$; the $4^{\text {th }}$ - the rats with modeled passive tobacco smoking combined with monosodium glutamate injection $(n=8)$.

The investigations were conducted following the general rules and regulations of the European Convention for the Protection of Vertebrate Animals Used for Experimental and Other Scientific Purposes (Strasbourg, 1986), the General Ethics on Animal Experimentation (Kyiv, 2001).

The rats of the second experimental group were exposed to tobacco smoke for 30 days. The model of the passive tobacco smoking was created by means of airtight chamber volume of 30 liters that allows fumigating animals, which could move freely [7]. Tobacco smoke, formed by smoking of 2 cigarettes Prima sribna (chervona) (containing $0.8 \mathrm{mg}$ of nicotine and $10 \mathrm{mg}$ of tar), was delivered into it through openings in the chamber. Four animals were simultaneously in the chamber for 30 minutes. The third group was administered MSG diluted in a distilled water at a dose of $30 \mathrm{mg} / \mathrm{kg}$ body weight (corresponds dose $2 \mathrm{~g}$ per day in humans) for 30 days via intragastrical tube [8]. MSG was produced by Sigma-Aldrich (USA). Rats of the fourth group were exposed to tobacco smoke and MSG administration in combination for 30 days.
On the 31-st day the experimental animals were euthanized under thiopental anesthesia and the whole blood was used for further investigation. The population of neutrophils was obtained by whole blood centrifugation at double density gradient 1.077 and 1.093 of Ficoll-Urografin. After 40 minutes of centrifugation at $4{ }^{\circ} \mathrm{C}$ and the speed of $1500 \mathrm{rpm}$, two interphases were formed. The upper interphase (on the border of plasma - Ficoll-Urografin density 1.077) consisted of mononuclear cells: $80 \%$ lymphocytes, $15-18 \%$ monocytes and $2-3 \%$ granulocytes. Lower interphase (on the border of solutions gradient density 1.077-1.092) was the population of neutrophils. The number of viable cells presented in a cell suspension was 98-99\% (Trypan blue exclusion test).

The analysis of cell samples to determine neutrophils with ROS (hydrogen peroxide) overproduction was evaluated by the flow laser cytometry method on flow cytometer Epics XL (Beckman Coulter, USA), using 2.7-dichlorodihydrofluorescein diacetate. The value of the studied parameter was expressed as a percentage (ratio of cells with ROS overproduction to general cell count $\times 100 \%$ ).

The evaluation of bioenergetics processes in the mitochondria of neutrophils was carried out using succinate dehydrogenase activity (SDG), which was studied by the reaction of the reduction of potassium ferricyanide, which solution had a yellow color, to colorless potassium ferrocyanide by succinate under the influence of SDG and cytochrome oxidase activity (CO) by the oxidation reaction of dimethyl-n-phenylenediamine. All spectrophotometric measurements were made on a SF-46 spectrophotometer.

Statistical processing of digital data was carried out using the software Excel (Microsoft, USA) and STATISTICA 6.0 (Statsoft, USA). The distribution of data was analyzed according to assessment of normality by Kolmogorov-Smirnov criterion. The obtained values had a normal distribution, so the difference between the groups was analyzed using the Student's t-criterion. All data were presented as $M($ mean $) \pm m$ (standard error). A probability level ( $p$ value) of less than 0.05 was considered to be statistically significant. The influence of factors on the indices was determined using the one-factor dispersion analysis (ANOVA). The linkage between the studied indices was established on the basis of the results of the correlation analysis using the Pearson correlation coefficient. 


\section{Results}

Our studies have proved that succinate dehydrogenase activity in leukocytes mitochondria in the mature male-rats under passive tobacco smoking significantly decreases by $26.6 \%$ compare to the control group (Table 1). Passive tobacco smoking combined with the monosodium glutamate injection is accompanied by an even greater decrease in succinate dehydrogenase activity (by $47.1 \%, p<0.001$ ) vs. the control group, which is $27.9 \%(p<0.001)$ below this indicator, providing isolated effect of tobacco smoke. In this case, the prolonged administration of glutamate monosodium results in a less significant decrease in succinate dehydrogenase activity (by $17.2 \%, \mathrm{p}<0.02$ ) compared to the control rats.

In the mature female rats, passive tobacco smoking is accompanied with the decrease in succinate dehydrogenase activity in blood mitochondria of leukocytes by $39.8 \%(p<0.001)$ compared to the control group. Passive tobacco smoking combined with the monosodium glutamate injection is accompanied by an even greater decrease in succinate dehydrogenase activity (by $62.1 \%, p<0.001$ ) compared to the control group, which is $37.1 \%(p<0.001)$ below this indicator, provided isolated effect of tobacco smoke. At the same time, prolonged administration of monosodium glutamate results in a decrease in succinate dehydrogenase activity by only $9.6 \%(p<0.05)$ compared to the control rats.

In the gender aspect, the intensity of changes in succinate dehydrogenase activity exceeded the rates of the mature male-rats in case of passive tobacco smoking by $13.2 \%$, in case of its combination with the monosodium

Table 1. Influence of passive tobacco smoking and monosodium glutamate on the energy processes in neutrophils mitochondria of rats $(M \pm m, n=8)$

\begin{tabular}{|c|c|c|c|c|}
\hline \multirow[b]{2}{*}{ Indicator } & \multicolumn{4}{|c|}{ Groups of experimental animals } \\
\hline & Intact & $\begin{array}{l}\text { Passive tobacco } \\
\text { smoking }\end{array}$ & $\begin{array}{l}\text { Monosodium } \\
\text { glutamate }\end{array}$ & $\begin{array}{l}\text { Passive tobacco smoking+ } \\
\text { monosodium glutamate }\end{array}$ \\
\hline \multicolumn{5}{|c|}{ Mature male-rats } \\
\hline $\begin{array}{l}\mathrm{SDG}, \\
\mathrm{nmol} /(\mathrm{mg} \times \min )\end{array}$ & $2.44 \pm 0.09$ & $\begin{array}{l}1.79 \pm 0.09 \\
p_{1}<0.001\end{array}$ & $\begin{array}{c}2.02 \pm 0.10 \\
p_{1}<0.02\end{array}$ & $\begin{array}{l}1.29 \pm 0.07 \\
\mathrm{p}_{1}<0.001 \\
\mathrm{p}_{2}<0.001 \\
\mathrm{p}_{3}<0.001\end{array}$ \\
\hline $\begin{array}{l}\mathrm{CO}, \\
\mathrm{nmol} /(\mathrm{mg} \times \min )\end{array}$ & $2.00 \pm 0.07$ & $\begin{array}{c}1.69 \pm 0.09 \\
p_{1}<0.05\end{array}$ & $\begin{array}{c}1.79 \pm 0.05 \\
p_{1}<0.05\end{array}$ & $\begin{array}{c}1.45 \pm 0.07 \\
\mathrm{p}_{1}<0.001 \\
\mathrm{p}_{2}>0.05 \\
\mathrm{p}_{3}<0.01\end{array}$ \\
\hline \multicolumn{5}{|c|}{ Mature female-rats } \\
\hline $\begin{array}{l}\mathrm{SDG}, \\
\mathrm{nmol} /(\mathrm{mg} \times \min )\end{array}$ & $2.51 \pm 0.08$ & $\begin{array}{l}1.51 \pm 0.07 \\
p_{1}<0.001\end{array}$ & $\begin{array}{c}2.27 \pm 0.06 \\
p_{1}<0.05\end{array}$ & $\begin{array}{l}0.95 \pm 0.05 \\
\mathrm{p}_{1}<0.001 \\
\mathrm{p}_{2}<0.001 \\
\mathrm{p}_{3}<0.001\end{array}$ \\
\hline $\begin{array}{l}\mathrm{CO}, \\
\mathrm{nmol} /(\mathrm{mg} \times \min )\end{array}$ & $2.07 \pm 0.09$ & $\begin{array}{l}1.57 \pm 0,06 \\
p_{1}<0.001\end{array}$ & $\begin{array}{c}2.03 \pm 0.08 \\
p_{1}>0.05\end{array}$ & $\begin{array}{c}1.29 \pm 0.04 \\
p_{1}<0.001 \\
p_{2}<0.05 \\
p_{3}<0.001\end{array}$ \\
\hline \multicolumn{5}{|c|}{ Immature male-rats } \\
\hline $\begin{array}{l}\mathrm{SDG} \\
\mathrm{nmol} /(\mathrm{mg} \times \min )\end{array}$ & $2.91 \pm 0.08$ & $\begin{array}{l}1.66 \pm 0.11 \\
p_{1}<0.001\end{array}$ & $\begin{array}{l}2.12 \pm 0.08 \\
p_{1}<0.001\end{array}$ & $\begin{array}{l}0.85 \pm 0.04 \\
\mathrm{p}_{1}<0.001 \\
\mathrm{p}_{2}<0.001 \\
\mathrm{p}_{3}<0.001\end{array}$ \\
\hline $\begin{array}{l}\mathrm{CO}, \\
\mathrm{nmol} /(\mathrm{mg} \times \min )\end{array}$ & $2.19 \pm 0.07$ & $\begin{array}{l}1.49 \pm 0.04 \\
p_{1}<0.001\end{array}$ & $\begin{array}{l}1.79 \pm 0.04 \\
p_{1}<0,002\end{array}$ & $\begin{array}{l}1.01 \pm 0.05 \\
\mathrm{p}_{1}<0.001 \\
\mathrm{p}_{2}<0.001 \\
\mathrm{p}_{3}<0.001\end{array}$ \\
\hline
\end{tabular}

Notes: $p_{1}$ - statistical significance of the differences compared to the intact animals;

$\mathrm{p}_{2}$ - statistical significance of the differences compared to the animals with experimental passive tobacco smoking;

$\mathrm{p}_{3}$ - statistical significance of the differences compared to the rats affected by monosodium glutamate. 
glutamate injection - by $15.0 \%$, in cases of prolonged administration of monosodium glutamate - by $7.6 \%$; the intensity of changes in succinate dehydrogenase activity was lower with respect to those in the mature male rats.

In the immature male rats, passive tobacco smoking is accompanied by a decrease succinate dehydrogenase (SDG) activity in mitochondria of blood leukocytes by $42.9 \%(p<0.001)$ compare to the control group. Passive tobacco smoking combined with the monosodium glutamate injection is accompanied by a more significant decrease in succinate dehydrogenase activity (in 3.4 times, $p<0.001$ ) compare to the control group, which is $48.8 \%(p<0.001)$ below this indicator, subject to the isolated effect of tobacco smoke. In this case, prolonged administration of monosodium glutamate results in a less significant decrease in succinate dehydrogenase activity (by $27.1 \%, p<0.001$ ) compared to the control rats.

In the immature male rats, the changes of succinate dehydrogenase activity exceed the indicators of the mature male rats of all experimental groups: in cases of modeled passive tobacco smoking - by $16.3 \%$, with the introduction of monosodium glutamate - by $9.9 \%$, in cases of modeled passive tobacco smoking combined with the monosodium glutamate injection - by $23.7 \%$.

Unidirectional changes are evidenced relation to the end-stage enzyme of mitochondrial respiratory chain - cytochrome oxidase (CO). In the mature male rats with modeled passive tobacco smoking, the activity of $\mathrm{CO}$ in mitochondria of blood leukocytes in the mature male rats decreased by $15.5 \%(p<0.05)$ compare to the control group. In the animals with modeled passive tobacco smoking combined with the monosodium glutamate it is also accompanied by a decrease in cytochrome oxidase activity (by $27.5 \%(p<0.001)$ compare to the control group, which does not significantly differ from this indicator, provided isolated effect of tobacco smoke. At the same time, prolonged administration of monosodium glutamate leads to a decrease in the activity of this enzyme (by $10.5 \%(p<0.05)$ compared with the control rats.

In the mature female-rats, passive tobacco smoking is accompanied by a decrease in CO activity in mitochondria of blood leukocytes by $24.1 \%(p<0.001)$ compare to the control group. In the animals with modeled passive tobacco smoking combined with the monosodium glutamate it is accompanied by an even greater decrease in CO activity (by $37.7 \%, p<0.001$ ) compare to the control group, which is $17.8 \%$ $(p<0.05)$ below this indicator, provided isolated effect of tobacco smoke. In this case, prolonged administration of monosodium glutamate do not lead to a significant reduction in CO activity compared with the control rats.

In the sex aspect, in the mature male rats with modeled passive tobacco smoking, the changes of cytochrome oxidase activity exceed by $8.6 \%$, in cases of passive tobacco smoking combined with the monosodium glutamate - by $10.2 \%$.

In the immature male rats, passive tobacco smoking is accompanied by a decrease in the activity of $\mathrm{CO}$ in mitochondria of blood leukocytes by $32.0 \%(p<0.001)$ compare to the control group. In the animals with modeled passive tobacco smoking combined with the monosodium glutamate it is accompanied by a more significant decrease in the activity of CO (by $53.9 \%, p<0.001)$ compare to the control group, which is $32.2 \%(p<0.001)$ below this indicator, provided isolated effect of tobacco smoke. In this case, prolonged administration of monosodium glutamate results in a significant decrease in CO activity (by $18.3 \%(p<0.002)$ compared with the control rats.

In the age aspect, in immature male-rats, the intensity of changes in CO activity was higher than those of the mature male-rats of all experimental groups: with passive tobacco smoking - by $16.5 \%$, with monosodium glutamate administration - by $7.8 \%$, in group passive tobacco smoking combined with the monosodium glutamate - by $26.4 \%$.

Our studies have showed that the percentage of neutrophils with ROS overproduction in the mature male-rats under passive tobacco smoking significantly increases by 2.2 times $(p<0.001)$ vs the control group (Table 2$)$. Passive tobacco smoking combined with the monosodium glutamate administration is accompanied by an even greater increase in the percentage of neutrophils with ROS overproduction (by 3.1 times, $p<0.001$ ) vs. the control group. The prolonged administration of monosodium glutamate results in a less significant decrease in the percentage of neutrophils with ROS overproduction (by $40.3 \%, p<0.001$ ) compared to the control rats.

In the mature female rats, passive tobacco smoking is accompanied with the increase in the percentage of neutrophils with ROS overproduction by 3.0 times $(p<0.001)$ compared to the control group. Passive tobacco smoking 
Table 2. Influence of passive tobacco smoking and monosodium glutamate on the percentage of neutrophils with ROS overproduction of rats $(M \pm m, n=8)$

\begin{tabular}{|c|c|c|c|c|}
\hline \multirow[t]{2}{*}{ Indicator } & \multicolumn{4}{|c|}{ Groups of experimental animals } \\
\hline & Intact & $\begin{array}{l}\text { Passive tobacco } \\
\text { smoking }\end{array}$ & $\begin{array}{l}\text { Monosodium } \\
\text { glutamate }\end{array}$ & $\begin{array}{l}\text { Passive tobacco smoking+ } \\
\text { monosodium glutamate }\end{array}$ \\
\hline \multicolumn{5}{|c|}{ Mature male-rats } \\
\hline ROS + -cells, \% & $17.98 \pm 0.86$ & $\begin{array}{c}39.44 \pm 2.56 \\
p_{1}<0.001\end{array}$ & $\begin{array}{c}25.23 \pm 1.19 \\
p_{1}<0.001\end{array}$ & $\begin{array}{c}56.39 \pm 2.82 \\
p_{1}<0.001 \\
p_{2}<0.01 \\
p_{3}<0.001\end{array}$ \\
\hline \multicolumn{5}{|c|}{ Mature female-rats } \\
\hline ROS $^{+}$-cells, \% & $14.95 \pm 0.98$ & $\begin{array}{l}45.21 \pm 1.70 \\
p_{1}<0.001\end{array}$ & $\begin{array}{c}18.71 \pm 0.78 \\
p_{1}<0.02\end{array}$ & $\begin{array}{c}60.95 \pm 3.07 \\
p_{1}<0.001 \\
p_{2}<0.02 \\
p_{3}<0.001\end{array}$ \\
\hline \multicolumn{5}{|c|}{ Immature male-rats } \\
\hline ROS + -cells, \% & $12.90 \pm 0.77$ & $\begin{array}{c}36.89 \pm 1.62 \\
p_{1}<0.001\end{array}$ & $\begin{array}{c}21.85 \pm 0.87 \\
p_{1}<0.001\end{array}$ & $\begin{array}{c}51.39 \pm 2.60 \\
p_{1}<0.001 \\
p_{2}<0.002 \\
p_{3}<0.001\end{array}$ \\
\hline
\end{tabular}

Notes: $p_{1}$ - statistical significance of the differences compared to the intact animals;

$\mathrm{p}_{2}$ - statistical significance of the differences compared to the animals with experimental passive tobacco smoking;

$\mathrm{p}_{3}$ - statistical significance of the differences compared to the animals affected by monosodium glutamate.

combined with the MSG administration is accompanied by an greater increase in the percentage of neutrophils with ROS overproduction (by 3.7 times, $p<0.001$ ) compared to the control group. At the same time, prolonged administration of MSG results in an increase in the percentage of neutrophils with ROS overproduction by only $25.1 \%(p<0.02)$ compared to the control rats.

The percentage of neutrophils with ROS overproduction in the immature male-rats under passive tobacco smoking significantly increases by 2.8 times $(p<0.001)$ vs the control group. Passive tobacco smoking combined with the MSG administration is accompanied by the greater increase in the percentage of neutrophils with ROS overproduction (by 4.0 times, $p<0.001$ ) vs. the control group. The prolonged administration of MSG results in a less significant increase in the percentage of neutrophils with ROS overproduction (by $69.4 \%, p<0.001$ ) compared to the control rats.

\section{Discussion}

The most important functions of mitochondria are oxidation of intermediate carbohydrate, lipid and protein metabolites such as pyruvate, fatty acids, acetate, and use of energy released upon decomposition of these compounds for the biosynthesis of ATP. Mitochondrial dysfunctions, associated with oxidative phosphorylation processes, structural integrity of mitochondria and information identity of their genetic apparatus, intensify in cases of oxidative stress, in diseases caused by metabolic disorders, and carcinogenesis [9].

Mitochondrial respiratory chain is the main intracellular source for generation of reactive oxygen species (ROS), and the activity of succinate dehydrogenase as a component of the $2^{\text {nd }}$ complex of the respiratory chain largely determines the rate of use of oxygen and synthesis of ATP in mitochondria [10]. Both succinate dehydrogenase and cytochrome oxidase determine the functioning of the chain of transformations of energy substrates [11].

Consequently, the intensity of energy processes in cases of passive tobacco smoking combined with the monosodium glutamate is significantly reduced in the animals of all experimental groups, which ultimately leads to 'energy starvation'. Decrease in cellular respiration and cellular energy abnormalities may 
be caused by endogenic intoxication and oxidative stress.

Mechanisms of tobacco-induced oxidative stress are primarily due to the fact that tobacco smoke is a substance that is directly a source of ROS as superoxide anion radical, hydrogen peroxide, and hydroxyl radical. In general, according to Yanbaeva D.G. and coauthors, tobacco smoke contains $10^{17}$ molecules of oxidants per one breath [12]. In addition, activation of inflammatory cells induced by tobacco smoke promotes the production of oxidants in tissues.

Many components of tobacco smoke can accumulate in mitochondria and affect the function of the respiratory chain, thereby affecting the cellular generation of adenosine triphosphate (ATP). In particular, carbon monoxide can interact with the components of the mitochondrial respiratory chain and suppress cytochrome oxidase [13].

Lykhatskyi P. H. et al. in the experiment on rats of different ages exposed with tobacco smoke for 45 days had established the inhibition of mitochondrial enzymes activity, indicating violations of bioenergetics processes in the body [14]. The most pronounced changes they had observed were in immature and senile rats.

In cases of administration of MSG, the mitochondrial respiratory chain is the main source of ROS. In addition, the increase in extracellular level of glutamate increases production of hydroxyl radicals. Studies by Sharma A. proved increased activity of a-Ketoglutarate dehydrogenase (a-KGDH) in cases of the use of MSG, which could activate the oxygen and form anion superoxide and hydrogen peroxide [15].

Most researches interweave oxidative stress and tissue damage through glutamate receptors. Glutamate receptors include three families of ionotropic receptors (NMDA N-methyl-D-aspartate, AMPA - a-amino-3hydroxy-5-methyl-4-isoxazolepropionic acid and kainate) and three groups of metabotropic receptors (mGluR) [5]. Activation of mGluR produces oscillatory increases in intracellular $\mathrm{Ca}^{2+}$. Increased $\mathrm{Ca}^{2+}$ influx leads to excessive uptake of $\mathrm{Ca}^{2+}$ into mitochondria, which can increase generation of ROS. Generation of ROS by $\mathrm{Ca}^{2+}$-loaded polarized mitochondria depletes the antioxidant potential of a cell, which causes final disruption of cytoplasmic homeostasis of calcium that can trigger numerous cellular reactions, including activation of nitric oxide synthase, protein kinase $C$ and inhibition of mitochondria enzymes activity [16].

Studies by S. Wu have proved that oxidative stress can even lead to fragmentation of mitochondria [17]. A study by S. Kumari et al. [18] showed that the glutamate induced cytotoxicity was associated with mitochondrial hyperpolarization, increased ROS production and enhanced oxygen consumption, glutamatecaused mitochondrial dynamic imbalance and reduced the number of cells with fragmented mitochondria, up to the splitting and activated autophagy.

Analyzing the correlation interactions between generation of ROS by blood neutrophils and their bioenergetics processes, without taking sex and age features into account, in the experimental groups of rats a negative moderate correlation $(r=-0.60 ; p<0.05)$ between the generation of ROS and SDG activity and a similar interaction $(r=-0.57 ; p<0.001)$ between the generation of ROS and CO activity, provided isolated effect of tobacco smoke, has been established.

Considering the division of rats by age and sex, in the mature male rats a significant negative correlation $(r=-0.85 ; p<0.05)$ between the ROS generation and succinate dehydrogenase activity and a similar interaction $(r=-0.85 ; p<0.05)$ between the generation of ROS and cytochrome oxidase activity, provided isolated effect of tobacco smoke. In case of passive tobacco smoking combined with the monosodium glutamate, installed an significant negative correlation $(r=-0.88 ; p<0.05)$ between the generation of ROS and cytochrome oxidase activity has been evidenced.

In the mature female rats with modeled passive tobacco smoking, a significant negative correlation $(r=-0.72 ; p<0.05)$ between the ROS generation and activity of cytochrome oxidase has been established.

In the immature male rats, a significant negative correlation between the generation of ROS and cytochrome oxidase activity has been established, provided isolated effect of tobacco smoke $(r=-0.78 ; p<0.05)$ as well as in cases of passive tobacco smoking combined with the monosodium glutamate $(r=-0.72$; $\mathrm{p}<0.05$ ).

Using ANOVA test, the influence of sex and age on succinate dehydrogenase and cytochrome oxidase activity of neutrophils mitochondria in the rats of the experimental groups has been determined. In cases of passive tobacco smoking combined with the monosodium 
glutamate, an age differences in the activity of mitochondrial enzymes $(p<0.05)$ have been proved.

\section{Conclusions}

Passive tobacco smoking is accompanied by an significant inhibition of bioenergetics processes in the mitochondria of circulating neutrophils in rats. The combination of passive tobacco smoking with the monosodium glutamate administration is accompanied by more pronounced changes.

In the sex aspect, the bioenergetics processes under the condition of passive tobacco smoking combined with the monosodium glutamate administration are more declining in mature female-rats, and with the age-old comparison of the changes in the activity of succinate dehydrogenase and cytochrome oxidase, was established their more intense reduction in immature male-rats.

Thus, the findings suggest that low dose intake of monosodium glutamate enhances the ability of tobacco smoke to disrupt the cell's bioenergetics processes by affecting the respiratory chain function and generation of ATP. Therefore, it is advisable to investigate the established toxic doses of monosodium glutamate, as well as to study the molecular mechanisms of 'safe' (allowed) doses of monosodium glutamate effect on a living organism.

\title{
СТАТЕВІ ТА ВІКОВІ АСПЕКТИ БІОЕНЕРГЕТИЧНИХ ПРОЦЕСІВ ПРИ ПАСИВНОМУ ТЮТЮНОПАЛІННІ ТА ЗАСТОСУВАННІ ГЛУТАМАТУ НАТРІЮ В ЕКСПЕРИМЕНТI
}

\author{
А. В. Руцка, І. Я. Криницька \\ ТЕРНОПІЛЬСЬКИЙ ДЕРЖАВНИЙ МЕДИЧНИЙ УНІВЕРСИТЕТ ІМЕНІ І. Я. ГОРБАЧЕВСЬКОГО, \\ ТЕРНОПІЛЬ, УКРАЇНА
}

Вступ. Активне та пасивне паління щороку є причиною понад 5 мільйонів смертей. Водночас технічний прогрес у харчовій та переробній областях сприяє використанню харчових добавок, які не завжди безпечні для здоров'я людини, наприклад, глутамату натрію.

Мета дослідження - визначити зміни активності мітохондріальних ферментів у щурів при пасивному палінні у поєднанні з тривалим введенням глутамату натрію в статевому та віковому аспектах.

Методи дослідження. Оцінку біоенергетичних процесів проводили за допомогою визначення активності сукцинатдегідрогенази та цитохромоксидази в мітохондріях циркулюючих нейтрофілів.

Результати. Пасивне паління у поєднанні з введенням глутамату натрію у зрілих шурів-самців супроводжується значним гальмуванням біоенергетичних процесів, про що свідчить зниження активності сукцинатдегідрогенази на 47,1 \% (p<0,001) порівняно з інтактними тваринами, що на $27,9$ \% ( $<<0,001)$ нижче цього показника при ізольованому ефекті тютюнового диму; $і$ зниженні активності цитохромоксидази на 27,5% (p<0,001) порівняно з контрольною групою.

Висновки. Таким чином, отримані дані свідчать про те, що глутамат натрію підвищує здатність тютюнового диму порушувати процеси біоенергетики клітини, впливаючи на функцію дихального ланцюга і генерацію АТФ. Тому дочільно досліджувати ефекти встановлених токсичних доз Е621, а також вивчати молекулярні механізми впливу його "безпечних" (дозволених) рівнів на організм.

КЛЮЧОВІ СЛОВА: пасивне тютюнопаління; глутамат натрію; цитохромоксидаза; сукцинатдегідрогеназа.

\section{References}

1. Reitsma MB. Smoking prevalence and attributable disease burden in 195 countries and territories, 1990-2015: a systematic analysis from the Global Burden of Disease Study 2015. The Lancet, 2017;389(10082),1885-1906.
2. Xu X, Bishop EE, Kennedy SM, Simpson SA, Pechacek TF. Annual Healthcare Spending Attributable to Cigarette Smoking: An Update. American Journal of Preventive Medicine; 2015;48(3): 326-33. 
3. Solomenchuk TM, Badzai AO, Protsko VV. Metabolic disorders in women with unstable angina, depending on the smoking habit. BukovinianMedical Bulletin; 2017;21,2(1):85-88 [In Ukrainian].

4. Peirson L, Muhammad UA, Meghan K, Parminder R, Sherifali D. Interventions for prevention and treatment of tobacco smoking in school-aged children and adolescents: A systematic review and meta-analysis. Preventive Medicine; 2016;85:20-31.

5. Husarova V, Ostatnikova D. Monosodium Glutamate Toxic Effects and Their Implications for Human Intake: A Review. Journal of Medical Internet Research; 2013;2013:1-12.

6. Likhatsky PG, Fira LS, Gonsky YaI. Dynamics of changes of markers of bioenergetic processes and cytolysis in rats after damage by sodium nitrite against the background of tobacco intoxication. Bulletin of Biology and Medicine Problems; 2017; 2(136):147-152 [In Ukrainian].

7. Lizurchik LV, Shade EV. Effect of tobacco smoke on the content of toxic elements in the rat. Bull. OGU; 2014;6(167):71-74 [In Russian].

8. Falaleeva TM, Samonina GE, Beregovaya TV, Dzyubenko NV, Andreev LA. The effect of glyprolines on the structural and functional state of the gastric mucosa and body weight of rats under conditions of prolonged administration of sodium glutamate. Physics of the Living; 2010;18,1:154-159 [In Russian].

9. Bilyk A, Negelya A, Garmanchuk L. Activity of cytochrome oxidase and succinate dehydrogenase in primary culture of transfected carcinoma of Lewis lungs at different stages of tumor growth. Bulletin of Taras Shevchenko National University of Kyiv; 2016;2(21):81-85 [In Ukrainian].

10. Voloshchuk ON, Marchenko MM. Enzymatic activity of components of the system of energy supply of mitochondria of blood leukocytes in the growth dynamics of Guerin's carcinoma. Siberian Cancer Journal; 2013;6(60):36-39 [In Russian].
11. Vasilenko OV, Bodnar OI, Vinyarskaya GB, Sinyuk YuV., Grubinko VV. Energy and nitrogen metabolism of uchlorella vulgaris beij(chlorophyta) under the influence of sodium selenite. Algology; 2014;24(3):297-301 [In Russian].

12. Yanbaeva DG, Dentener MA, Creutzberg EC, Wesseling G, Wouters EF. Systemic effects of smoking. Chest; 2007;131(5):1557-66.

13. Heijink IH, Pouwels SD, Leijendekker C, de Bruin HG, Zijlstra GJ, van der Vaart $\mathrm{H}$, ten Hacken $\mathrm{NH}$, van Oosterhout AJ, Nawijn MC, van der Toorn M. Cigarette Smoke-Induced Damage-Associated Molecular Pattern Release from Necrotic Neutrophils Triggers Proinflammatory Mediator Release. American Journal of Respiratory Cell and Molecular Biology. 2015 May;52(5):554-62.

14. Lykhatskyi PH., Fira LS., Fedorovich UM. Proteins oxidative modification and mitochondrial enzymes activity in rats of different ages under affection by sodium nitrites and tobacco smoke. Ukrainian Biopharmaceutical Journal; 2017;3(50): 38-46.

15. Sharma A. Monosodium glutamate-induced oxidative kidney damage and possible mechanisms: a mini-review. Journal of Biomedical Science; 2015; 22:93.

16. Ward MW, Rego AC, Frenguelli BG, Nicholls DG. Mitochondrial Membrane Potential and Glutamate Excitotoxicity in Cultured Cerebellar Granule Cells J Neurosci. 2000;20(19):7208-19.

17. Wu S, Zhou F, Zhang Z, Xing D. Mitochondrial oxidative stress causes mitochondrial fragmentation via differential modulation of mitochondrial fissionfusion proteins. FEBS J; 2011;278:941-954.

18. Kumari S, Mehta SL, Li PA. Glutamate Induces Mitochondrial Dynamic Imbalance and Autophagy Activation: Preventive Effects of Selenium. PLoS ONE; 2012;7(6):e39382. 